\title{
濤沸湖河口部における河口閉塞の発生要因 \\ STUDY ON ESTUARY CHOKING IN LAKE TOUFUTSU
}

\author{
堀江岳人 ${ }^{1} \cdot$ 鎌田英人 $^{2} \cdot$ 仁禮恵昭 $^{2} \cdot$ 橋本孝治 $^{3} \cdot$ 橋本佳祐 $^{1} \cdot$ 中村精治 $^{2}$ \\ Takehito HORIE, Hideto KAM ADA, Keisho NIREI, Kouji HASHIM OTO \\ Keisuke HASHIMOTO and Seiji NAKAMURA
}

\begin{abstract}
Recently, estuary choking occurs several times in Toufutsu river mouth every winter, and the dredging is carried out after occurrence of estuary choking. Estuary choking affect flood control, fisheries in lake, and so forth. In this study, we aimed to reveal the mechanism of estuary choking by observations, which are current observation, water level observation, sediment survey, and video monitoring at the entrance of the Toufutsu Lake. Followings were major accomplishments of this study. (1)W hen high tide level during the flood tide and incident wave from the right bank side occurred at the same time, estuary choking occurred in Toufutsu estuary. (2) In case that ground level of inland area is higher than the crown height of the revetment, estuary choking is likely to be caused by swash.
\end{abstract}

\section{1はじめに}

河口閉塞の発生は, 出水時における治水上の安全のみ ならず，汽水域に生息・生育する生物環境に多大な影響 を及ぼすと考えられる。河口閉塞の発生要因は, 河川流 による上流からの土砂の堆積, 波浪による河道内への土 砂の押し込み, 沿岸漂砂による砂州の形成などが単独も しくは重複することにより発生する場合が多い（例えば, 椹木, 1968). 河口閉塞の発生事例とその要因として, 高橋ら（2005）は，1994年に発生した宮城県の七北田川 での年5回に渡って発生した完全閉塞について, 夏に発 生した異常渇水の影響すなわち自流量の減少を要因とし て挙げている．小山ら（2005）は，青森県の高瀬川河口 での閉塞について, 有義波波高の発達に伴う砂州の発達 過程を砂面変動観測などから解明し, 河口部画像デー夕 及び水位データを用いて維持管理を目的とした河口監視 システムを提案している，中野ら（2006）は，高知県の 物部川河口での閉塞について, 秋から春にかけての岸向 き漂砂の卓越時に起こりやすいことを指摘している. 田 中ら（2012）は, 七北田川河口における東北地方太平洋 沖地震津波後の地形変化について, 空中写真・水位デー 夕を基に河口閉塞の進行過程，洪水による新たな河口部 の形成, 人工開削の効果を検証し, 津波来襲後の河口部 の地形変化の過程を詳細に説明している. このように, 河口閉塞は, 各河口域に扔ける外力条件や地形条件によ り発生メカニズムが異なると考えられる。そそのため，閉 塞対策を実施する場合は閉塞要因を明確化し，その要因 に対する適切な河口処理や維持管理が求められる.

\begin{tabular}{|c|c|c|}
\hline $\begin{array}{l}1 \text { 正会員 } \\
2\end{array}$ & 工修 & $\begin{array}{l}\text { (株)アルファ水工コンサルタンツ 技術部 } \\
\text { オホーツク総合振興局 網走建設管理部 }\end{array}$ \\
\hline 3 正会員 & 博 (工) & (株)アルファ水工コンサルタンツ 企画部 \\
\hline
\end{tabular}

北海道網走市に位置する濤沸湖（図-1）は, 網走市及 び小清水町に跨る周囲 $27.3 \mathrm{~km}$, 面積約 $9.3 \mathrm{~km}^{2}$, 平均水深 約 $3.5 \mathrm{~m}$ の感潮湖である. 濤沸湖とオホーツク海域の間は, 延長約400mの河道で接続されており, 河口部では左岸・ 右岸共に導流堤が1977年に設置されている（写真-1）。流 域面積は約 $9.3 \mathrm{~km}^{2}$ であり, 自流量が $10 \mathrm{~m}^{3} / \mathrm{sec}$ 以下 3 本の 小河川が濤沸湖内へ注いでいる（図-1)。濤沸湖周辺海域 の汀線は，1977年の導流堤設置により左岸側が前進，右 岸側が後退したが，その後はほぼ安定している状況にあ る(図-2)。な押, 汀線変化特性より, 濤沸湖河口部周辺 での沿岸漂砂の卓越方向は, 左岸から右向きと考えられる.

濤沸湖では, 冬季にオオ八クチョウが飛来するなど生 物生息に貴重な湖沼として，2005年にラムサール条約の 指定を受けている。，一方，河口部では，近年，河口閉塞 が頻繁に発生し, 漁業操業に支障を及ぼしている他, 湖 内で結水した水塊が河川流下を阻害するなど治水上の問 題が生じている，また，濤沸湖とその下流側河道との接 続地点に抒いて, 導流堤設置後から湖口砂州が発達し, 近年では一部が陸地化したため, キッネが砂州を渡って オオハクチョウを襲うなどの被害が生じている.

本研究では、河口閉塞の発生要因及び河口砂州の発生 状況を明らかにすることを目的として、濤沸湖河口部に て水位、流速等の水文観測を実施した。また、河口閉塞 の進行過程を視覚的に把握することを目的として、ネッ トワークカメラ（以下、NWカメラ）による定点撮影を 実施した。更に, 河口閉塞の発生要因を検証するため, 河口域を対象とした遡上波シミュレーションを実施した.

\section{2. 現地調查内容}

現地調查は、2010年9月～12月（期間1）、2011年11月 〜12月（期間2）及び2013年11月～2014年1月（期間3） 


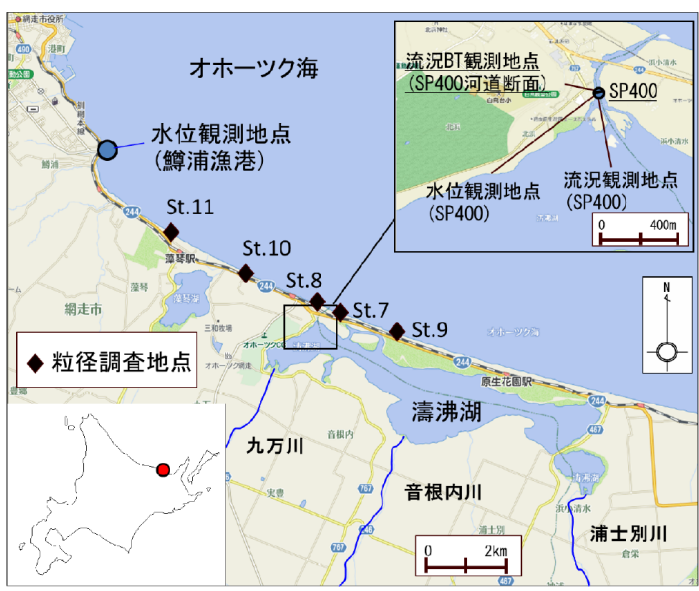

図-1 調查地点

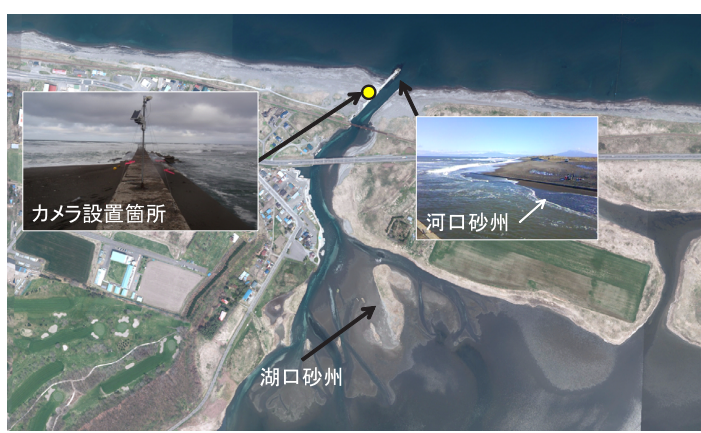

写真-1 濤沸湖 (2012 年, ((株) シン技術コンサル撮影 $)$ )

の3期間に渡り実施した（表-1）。この内、期間3において 河口が完全に閉塞した。 なお，紙面の制限上，一部の調 査結果については割愛する.

\section{(1) 底質調査}

濤沸湖周辺における海域汀線部の粒径分布の把握を目 的として, 沿岸部の計5地点（st.7〜st.11）において底質 調査を実施した（図-1).

\section{（2）ネットワークカメラ観測の概要}

河口部における地形変化を視覚的に把握するため, 小 型ソーラーパネル及び携帯電話ユニットを付帯したN W カメラ（キヤノン製VB-C60）を用いた定点撮影を実施し た. NWカメラの設置位置は, 河口部左岸側に設置した (写真-1)。サンプリング時間は, 夜間を除く6:00〜 18 ： 00で20分毎に1枚撮影を行った。
表-1 調査概要の一覧

\begin{tabular}{c|c|c}
\hline 調查項目 & 調查場所 & 調查期間 \\
\hline 水位 & $\begin{array}{c}\text { SP400, } \\
\text { 鱒浦漁港 }\end{array}$ & $\begin{array}{l}\text { 期間1 }: 2010 / 9 / 18 \sim 12 / 24 \\
\text { 期間2 }: 2011 / 9 / 1 \sim 12 / 1 \\
\text { 期間3 }: 2013 / 11 / 8 \sim 2014 / 1 / 15\end{array}$ \\
\hline 流速・波浪 & SP400 & $\begin{array}{l}\text { 期間1 }: 2010 / 9 / 19 \sim 10 / 23 \\
\text { 期間2 }: 2011 / 9 / 1 \sim 12 / 1\end{array}$ \\
\hline 断面流速 & SP400 & 期間2 $: 2011 / 12 / 23$ 毎正時 \\
\hline NW カメラ & 河口左側 & $\begin{array}{l}\text { 期間1 }: 2010 / 9 / 18 \sim 12 / 24 \\
\text { 期間3 }: 2013 / 11 / 8 \sim 2014 / 1 / 15\end{array}$ \\
\hline \multicolumn{2}{|l}{}
\end{tabular}

（3）水文観測の概要

\section{a) 水位観測の概要}

河道内及び海域における水位変動を把握するため, SP400及び鱒浦漁港（図-1）にて，水圧式水位計（侏)離 合社製，以下，水位計）を用いた定点水位観測を実施し た。鱒浦漁港では波浪の影響を直接受けにくい港内, SP400では左岸側の岸壁に水位計をそれぞれ設置した. データサンプリング時間は，10分毎の瞬間值とした。

\section{b) 波浪・流況観測の概要}

河道内における流況及び遡上波浪の把握を目的とし て, SP400にてWave-Hunter（(有）アイオーテクニック 製，以下，WH）を用いた定点観測を行った。WHは，左 岸から約 $10 \mathrm{~m}$ 地点に鋼製の架台を用いて固定し, WHの 流速センサーが河床から約 $0.5 \mathrm{~m}$ 高さになるように設定 した。データサンプリング時間は，1時間毎に0.5秒で 20 分間の連続観測とした.

\section{3. 調査結果}

各調査結果について，以下に示す。なお，調査結果は， 紙面の都合上，期間3の河口閉塞時における観測結果， 期間1において観測された河口砂州の発達〜消失の過程, 濤沸湖河口周辺沿岸部の地形特性ついて主に説明する.

\section{（1）沿岸部の粒径}

濤沸湖周辺における汀線部の粒径は, ほぼ同じ分布特 性を示しており，その中央粒径は約 $0.26 \mathrm{~mm}$ （細砂〜中 砂）であった（図-3）。おお, 河口左岸側の粒径と比較し て，右側の粒径の方がやや粗かった。

\section{（2）河口閉塞発生時の調査結果（期間3）}

a) ネットワークカメラの結果

期間3のNW カメラ観測開始直後の2013年11月9日では,

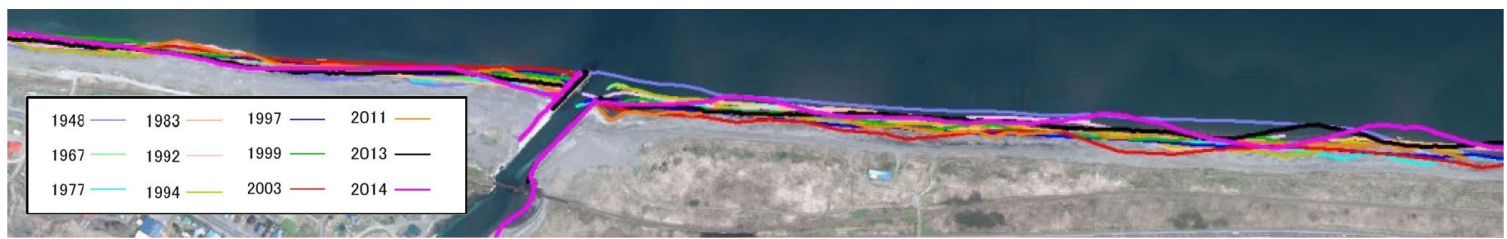

図-2 汀線変化濤沸湖河口部周辺における汀線変化 


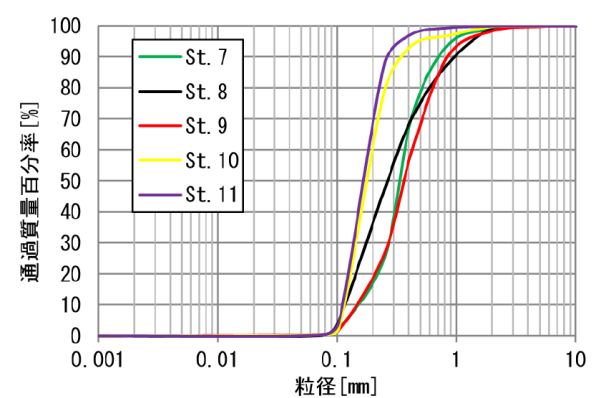

図-3 沿岸部の粒径分布

右岸側導流堤前面において河口砂州の発達が確認できた (写真-2 (A))。11月19日前後では、右岸側導流堤の堤内 側陸地部まで波浪が遡上しており（写真-2 (B))，それ に伴って徐々に河口が閉塞していき，11月20日に完全に 閉塞した（写真-2 (C)).11月23日から河口開削工事が 行われ（写真-2 (D)), 工事後から翌年1月15日の観測終 了まで河口閉塞は発生しなかった。なお，河口開削工事 での浚渫土砂量は, 約 $3,000 \mathrm{~m}^{3}$ であった.

\section{b) 水理特性}

河道内SP400の水位は（図-4 (a)), 基本的に鰌浦漁港
での潮位変動と同期していたが，潮位変動の大きさすな わち振幅が小さく，位相差が見られた，完全閉塞が発生 した11月20日から河道開削が実施された11月23日の期間 において，SP400の水位は潮位変動と同期した変動が見 られず，緩やかに水位が直線的に高くなっていた（図-4 中のB Cの期間)。 11 月 19 日に, 最大 $5 \mathrm{~mm} / \mathrm{hr}$ の降雨量が

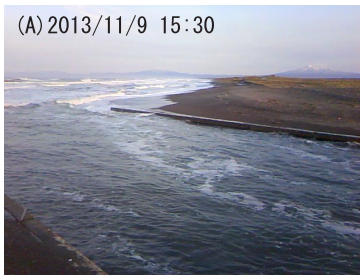

(C) $2013 / 11 / 21 \quad 12: 00$

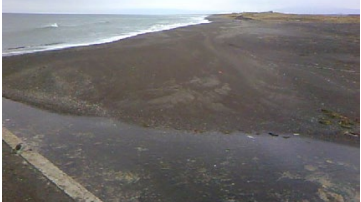

写真-2 NWカメラ観測結果
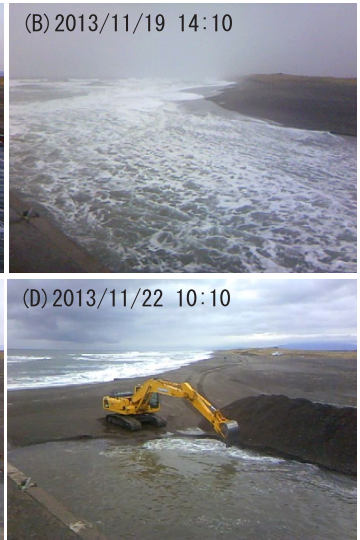

(a)

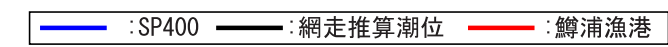

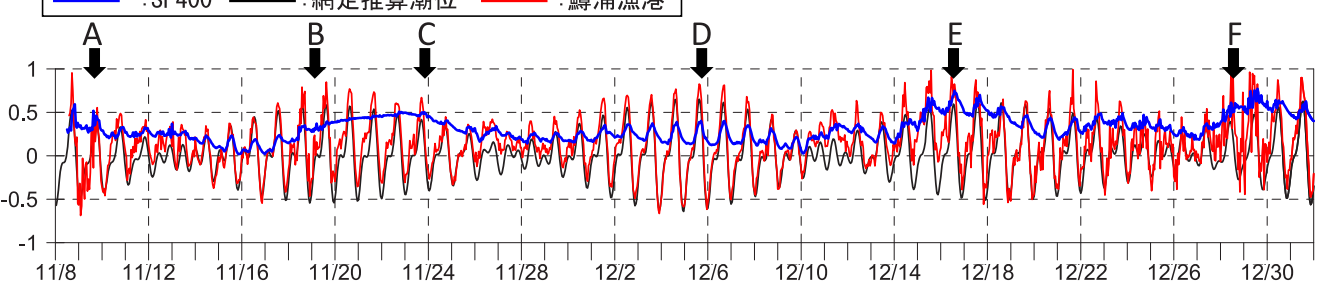

(b)

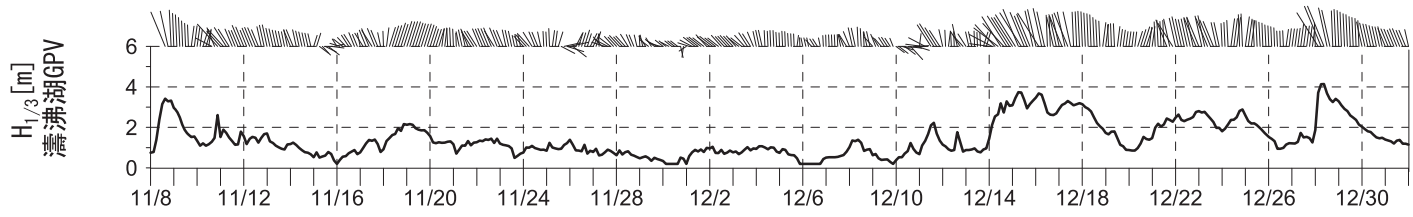

(c)

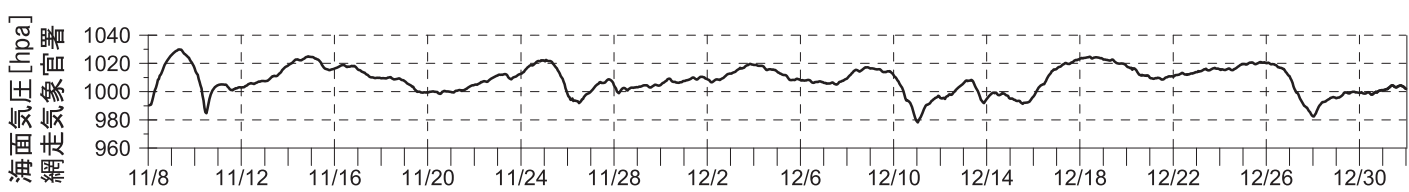

(d)

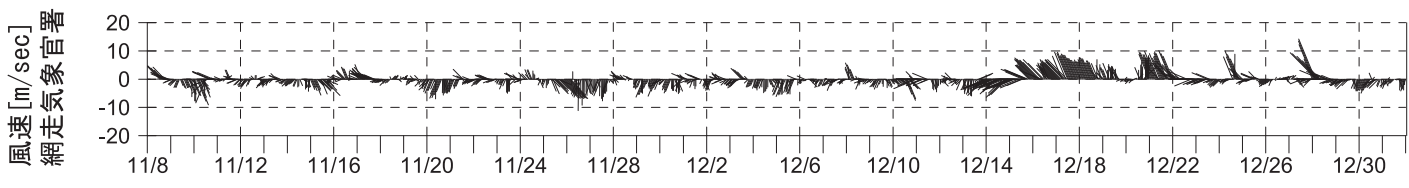

(e)

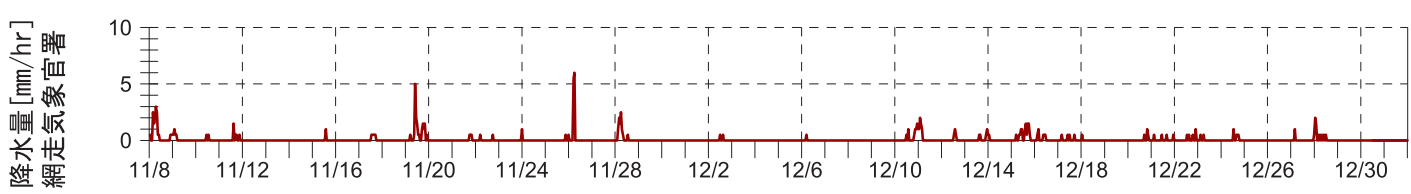

図-4 水文観測結果及び気象・海象デー夕 (期間3，2013 年)，（a) SP400，鰌浦漁港の観測水位及び網走推算潮位(気象庁)，（b)上段 : 波浪ベクトル，下段：有義波波高(濤沸湖沖GPV データ)，(c) 海面気圧(網走気象官署), (d) 風速ベクトル (同), (e) 降水量 (同) 
あったことから (図-4 (e)), 河口閉塞によって湖内の水 位が上昇しやすい条件であったと考えられる，河口閉塞 が発生した11月19日前後では，大潮の高潮時にあたる時 刻において，右入射で周期約10.5秒のうねり性波浪が来 襲していた（図-4（b)）。12月16日前後及び12月29日前後 の大潮の高潮時において, SP400の水位が上昇していた (図-4中のE及びF)。これは，同時期における有義波波高 の増大に伴うウェーブセットアップに加え, 海面気圧の 低下（図-4 (c)）や海域から湖内に向かう $\mathrm{N}$ 系の風の卓 越（図-4 (d)）が要因して挙げられる。なお，図-4中のE 及びFの期間では, 河口閉塞時よりも有義波波高が大き く, 水位も上昇していたが, 河口閉塞は発生しなかった.

\section{（3）河口砂州の発達〜消失時の調查結果（期間 1)}

右岸側導流堤前面に現れる河口砂州の発生事例を示 す. 期間1の2010年9月26日に左入射の約 $2.5 \mathrm{~m} の$ 有義波が 来襲し, 右岸側導流堤の先端部付近から土砂の堆積が進 み, 河口砂州が形成された（写真-3）。その後, 高波浪が 来襲しなかった大潮時の干満によって河口砂州は徐々に 湖内側へ移動し消失した.

図は割愛するが，期間1及び期間2の実施された流況観 測より，河道SP400における順流と逆流の流速に着目す ると，全観測期間中に打いて基本的に順流よりも逆流の 方が速かった（堀江ら，2012）。なお，入退潮時間内に おける順流と逆流の作用時間は, 順流の方が逆流よりも 約2倍長かった。

以上の結果を基に，上述の砂州の発達〜消失を含む期 間1全期間での河道内SP400での通過漂砂量を, ブラウン の式を適用し算出した（堀江ら，2012）。その結果，全 通過流砂量は海域向きと比較して湖口向きの方が多いこ

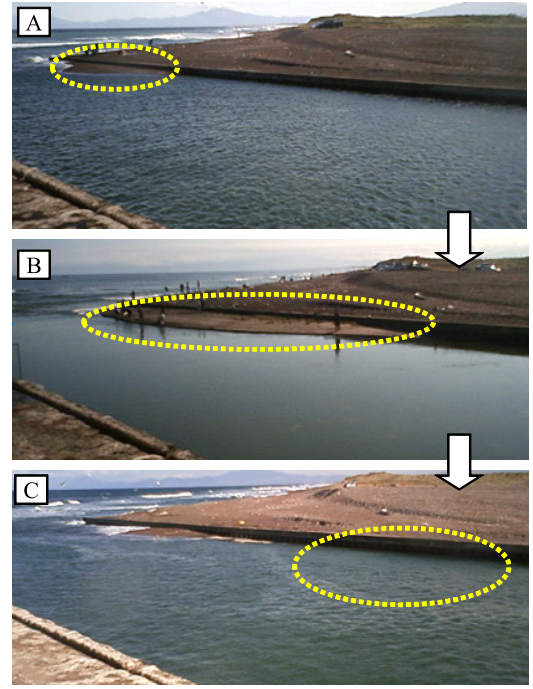

写真-3 河口砂州の発達・消失過程 (A-2010/9/26, B-10/7, C-10/15)
とから, 河口砂州は, 湖内砂州形成の一要因となってい ると考えられる.

\section{4. 濤沸湖河口部における河口閉塞の要因の考察}

濤沸湖では，これまで冬季において高波浪が連続で発 生した場合に河口閉塞が発生した事例が報告されてい る. 一方, 河口が完全に閉塞した期間3の2013年11月19 日前後では, 顕著な高波浪は発生していない. そこで, 河口閉塞発生時における海象条件を基に遡上波シミュ レーションを実施し, 河口閉塞の発生要因について検討 した

（1）遡上波シミュレーション

\section{a) 計算モデル}

計算モデルの基礎方程式は、水深を場所の関数とした 修正ブシネスク方程式（M adsen and Sorensen、1992）を 用いた。遡上波解析は, 修正ブシネスク方程式による流 動場の計算に, 平山ら（2004）の方法による遡上モデル を組み込んだモデルを用いた。地形モデルは，2013年3 月に実施された河道横断測量結果及び海域深浅測量結果 を基に構築した（図-5)

\section{b) 外力条件}

遡上波シミュレーションにおける外力条件は, 河口閉 塞が発生した2013年11月18日21時（CASE-1）のGPV 波浪 データ及び鱒浦漁港における水位観測データを用いた. また，参考に河口砂州の発達が見られた11月8日15時 (CASE-2) についても計算を実施した（表-2)。なお, CASE-1は右入射, CASE-2は左入射の波向である.

\section{c) 遡上波シミュレーションの結果}

河口閉塞発生時（CASE-1）は，右岸天端高を超えて遡 上波が河道内へ流入していることがわかる（図-6 (a)). その結果, 陸上部の砂が河道内へ流入したことにより、 河口閉塞が生じたと考えられる。一方, 河口砂州発達時 (CASE-2) では, CASE-1と比較して浸水深が小さく, ま た, 河道内方向への流速が卓越していないため, 河道内 への土砂流入量が少なく，河口閉塞には至らなかったと 考えられる.

\section{（2）河口閉塞の一要因}

護岸等の天端高は、治水上安全な高さに設定される。 一方、中小河川ではその規模にもよるが、濤沸湖河口部 における右岸のように（図-7）, 堤内側地盤高が護岸天端 高より高い場合は、遡上波の作用によって陸上部の砂が 一気に河道内へ流入し、河口閉塞を引き起こす要因とな

表-2 遡上波計算の外力条件

\begin{tabular}{c|c|c|c|c}
\hline ケース & 波高 & 周期 & 波向 & 潮位 \\
\hline CASE-1 & $2.2 \mathrm{~m}$ & $10.3 \mathrm{~s}$ & $\mathrm{~N} 40^{\circ} \mathrm{E}$. & $0.7 \mathrm{~m}$ \\
\hline CASE-2 & $3.6 \mathrm{~m}$ & $9.4 \mathrm{~s}$ & $\mathrm{~N} 0^{\circ} \mathrm{E}$ & $0.42 \mathrm{~m}$ \\
\hline
\end{tabular}




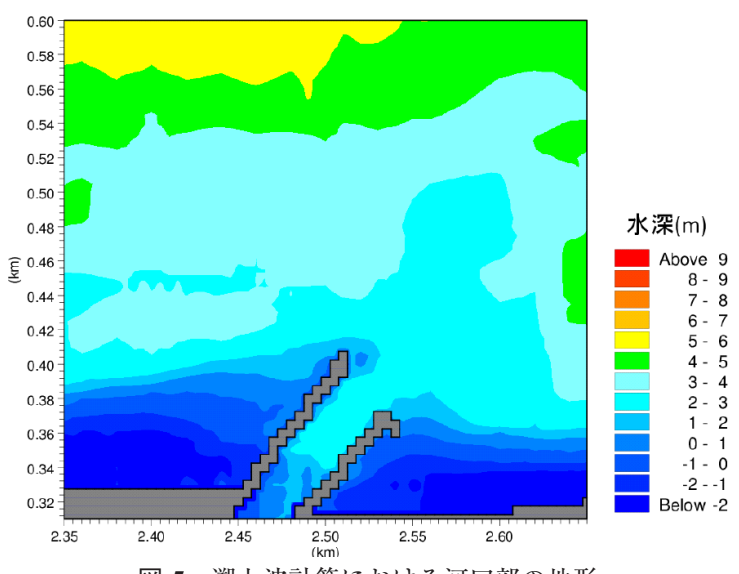

図-5 遡上波計算における河口部の地形

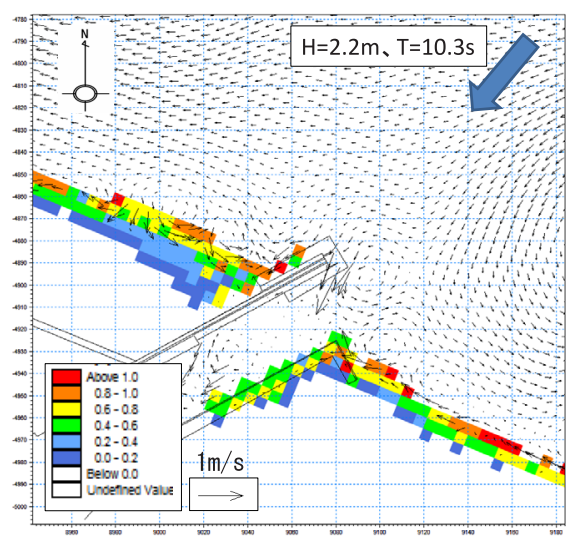

(a)CASE-1:河口閉塞発生時

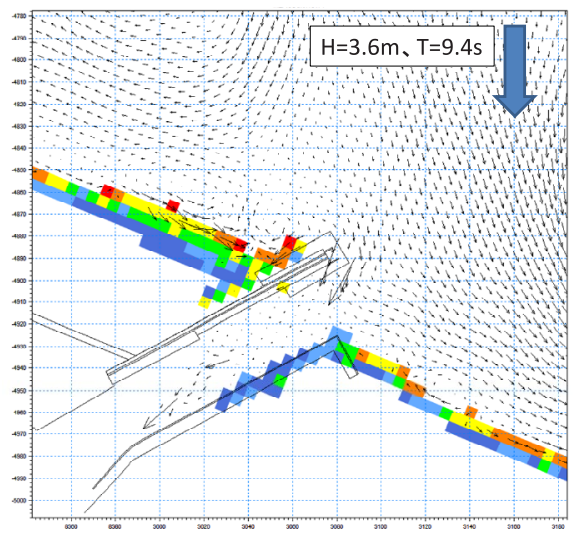

(b)CASE-2:河口砂州発達時

図-6 遡上波計算結果深水深図 ※矢印は流速べクトル

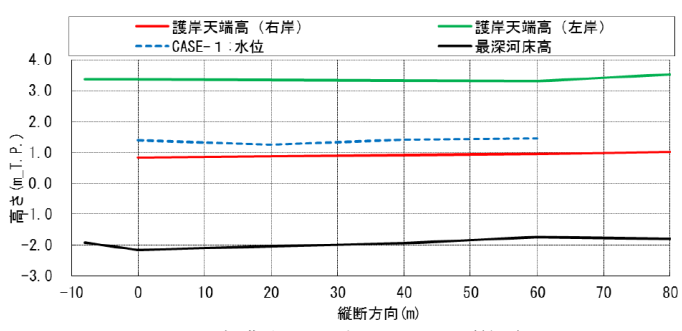

図-7濤沸湖河口部における縦断図

る場合が考えられる。

\section{5. 主要な結論と今後の課題}

本研究による主要な結論を, 以下より示す.

（1）NWカメラ観測及び遡上波シミュレーション結果 より，期間3で発生した河口閉塞は，大潮の高潮期で水 位が高く，かつ右入射の波浪が卓越した条件下において 発生した。（2）濤沸湖河口部のように，堤内側地盤高が 護岸天端高より高い場合は, 遡上波の作用によって陸上 部の砂が河道内へ流入し, 河口閉塞を引き起こす要因と なっている.

\section{参 考 文 献}

小山幸男 - 金枝富勝 - 畠山仁志 - 高木利光 - 藤井裕之 (2005)： 高瀬川河口閉塞機構の解明と維持管理方法の提案, 第52 回海講論文集, pp. 571-575.

椹木 亨 (1968)：河口閉塞に伴う河道内水位の変化について --河口閉塞機構に関する基礎的研究, 第三報--, 第15回海 講論文集, pp. 195-202.

高橋文彦・田中 仁・高橋 淳 (1976)：1994年渇水期に観測 された七北田川河口の完全閉塞, 第42回海講論文集, pp. 581-585.

田中 仁· Mohammad Bagus A DITYAWAN · 真野 明 (2012)： 東北地方太平洋沖地震津波後の七北田川河口閉塞とその 後の地形変化, 土木学会論文集B2 (海岸工学), Vol. 68, No. 2, pp. 601-605.

中野 晋·石丸訓之・岡本誠一郎（2006）：物部川における河 口閉塞の現状と河口部潮位変動, 第53回海講論文集, pp. 601-605.

平山克也・平石哲也（2004）：ブシネスクモデルによる砕波・ 遡上計算とその適用性, 海岸工学論文集, 第51巻, 土木 学会, pp. 11-15.

堀江岳人 · 仁禮恵生 - 工藤高志 - 中村知道 - 齋藤正美 - 橋本 孝治・澤本正樹・近藤淑郎（2012）：濤沸湖内における砂 州の形成過程に関する考察, 土木学会論文集B2（海岸工 学), Vol. 68, pp. 636-640. 